\title{
IMPLEMENTASI PERMENDAGRI NOMOR 20 TAHUN 2018 TENTANG PENGELOLAAN KEUANGAN DESA DI KECAMATAN TOMBATU
}

\author{
Piter J. Mokalu \\ Universitas Negeri Manado \\ pitermokalu@unima.ac.id
}

\begin{abstract}
Abstrak
Desa adalah desa dan desa adat atau yang disebut dengan nama lain, selanjutnya disebut Desa, adalah kesatuan masyarakat hukum yang memiliki batas wilayah yangberwenang untuk mengatur dan mengurus urusan pemerintahan, kepentingan masyarakat setempat berdasarkan prakarsa masyarakat, hak asal usul,

dan/atau hak tradisional yang diakui dan dihormati dalam sistem pemerintahan Negara Kesatuan Republik Indonesia.

Desa merupakan garda terdepan dalam pelayanan masyarakat, hal ini dikarenakan desa bersentuhan langsung dengan masyarkat, kenyataan itu menjadi dasar pemerintah sekarang ini untuk membangun Indonesia dari desa, hal itu ditunjang dengan pemberian dana yang melimpah, namun pada kenyataannya kesiapan masing-masing desa berbedabeda.

Keuangan Desa adalah semua hak dan kewajiban Desa yang dapat dinilai dengan uang serta segala sesuatu berupa uang dan barang yang berhubungan dengan pelaksanaan hak dan kewajiban Desa. Pengelolaan Keuangan Desa adalah keseluruhan kegiatan yang meliputi perencanaan, pelaksanaan, penatausahaan, pelaporan, dan pertanggungjawaban keuangan Desa. Pemegang Kekuasaan Pengelolaan Keuangan Desaadalah kepala Desa yang karena jabatannya mempunyai kewenangan menyelenggarakan keseluruhan pengelolaan keuangan Desa.
\end{abstract}

Kata Kunci: Implementasi, Pengelolaan, Keuagan Desa 


\section{PENDAHULUAN}

Desa memiliki kedudukan yang sangat strategis dalam sistem pemerintahan Indonesia mengingat bahwa desa merupakan satuan pemerintahan terkecil yang memiliki peranan fundamental bagi negara. Desa mempunyai otonomi yang disebut dengan otonomi desa. Dengan disahkannya UU Desa maka diprediksikan desa akan memasuki babak baru untuk penataan dan pembangunan wilayahnya yang datang membawa harapan-harapan baru bagi kehidupan kemasyarakatan dan pemerintahan yang ada di desa. Penerapan dan pelaksanaan otonomi desa diharapkan membawa semangat perubahan dalam mewujudkan tujuan pembangunan yaitu meningkatkan kesejahteraan masyarakat desa. Desa sebagai pemerintahan terkecil di Republik Indonesia sangatlah perlu untuk memiliki sistem yang mapan serta pentingnya melakukan penataan desa sebagai upaya mewujudkan pemerintahan desa yang efektif dan efisien. ${ }^{1}$ Adapun salah satu subkomponen yang sangat fital dari keseluruhan komponen yang termasuk dalam ruang lingkup sistem penataan desa adalah komponen keuangan desa.

Keuangan Desa adalah semua hak dan kewajiban Desa yang dapat dinilai dengan uang serta segala sesuatu berupa uang dan

1 Siti Khoiriah, Utia Meylina, "Analisis Sistem Pengelolaan Dana Desa", Masalah-Masalah Hukum, Jilid 46, No. 1, Januari 2017, hlm. 20-29. barang yang berhubungan dengan pelaksanaan hak dan kewajiban Desa. ${ }^{2}$ Selanjutnya dinyatakan: Pengelolaan Keuangan Desa adalah keseluruhan kegiatan yang meliputi perencanaan, pelaksanaan, penatausahaan, pelaporan, dan pertanggung jawaban keuangan Desa. ${ }^{3}$

Keuangan Desa dikelola berdasarkan asas transparan, akuntabel, partisipatif serta dilakukan dengan tertib dan disiplin anggaran. Anggaran Pendapatan dan Belanja Desa (APB Desa) merupakan dasar pengelolaan keuangan Desa dalam masa 1 (satu) tahun anggaran mulai tanggal 1 Januari sampai dengan tanggal 31 Desember.

Permendagri Nomor 20 Tahun 2018 tentang Pengelolaan Keuangan Desa ditetapkan pada tanggal 11 April 2018 oleh Menteri Dalam Negeri Republik Indonesia Tjahjo Kumolo. Dilihat dari umur berlakunya Permendagri tersebut dapat dikatakan belumlah lama.

Pemerintah telah memprogramkan bantuan Satu Milyar Satu Desa (SAMISADE),${ }^{4}$ dengan demikian semua desa

\footnotetext{
${ }^{2}$ Kementerian Dalam Negeri, Peraturan Menteri Dalam Negeri Tentang Pengelolaan Keuangan desa, Permendagri Nomor 20 Tahun 2018, Berita Negara Republik Indonesia Nomor 611 Tahun 2018, Ps. 1 angka 5.
}

\footnotetext{
${ }^{3}$ Kementerian Dalam Negeri, Peraturan Menteri Dalam Negeri Tentang Pengelolaan Keuangan desa, Permendagri Nomor 20 Tahun 2018, Berita Negara Republik Indonesia Nomor 611 Tahun 2018, Ps. 1 angka 6.
} 
termasuk desa-desa yang berada di lingkungan Kecamatan Tombatu mendapatkan bantuan Satu Milyar. Dana desa yang telah diprogramkan oleh pemerintah tersebut harus menjadi kekuatan suatu desa dalam membangun dan mengembangkan desa tersebut agar menjadi desa yang mandiri dan kuat.

Semua desa yang mendapatkan dana desa harus dapat melakukan pengelolaan keuangan desa secara maksimal sesuai ketentuan peraturan perundang-undangan tentang pengelolaan keuangan pada umumnya dan pengelolaan keuangan desa berdasarkan Permendagri Nomor 20 Tahun 2018 pada khususnya. "Pengelolaan Keuangan Desa adalah keseluruhan kegiatan yang meliputi perencanaan, pelaksanaan, penatausahaan, pelaporan, dan pertanggungjawaban keuangan Desa." ${ }^{5}$ Keuangan desa dikelola berdasarkan asasasas transparan, akuntabel, partisipatif serta dilakukan dengan tertib dan disiplin anggaran. Pengelolaan keuangan desa, dikelola dalam masa 1 tahun anggaran yakni mulai tanggal 1 Januari sampai dengan tanggal 31 Desember. Oleh karena itu semua perangkat desa apalagi yang

4 Vijay L. Tumiwa, "Kinerja Dinas Pertanian Kabupaten Minahasa Tenggara Dalam Program Bantuan Peningkatan Hasil Pertanian Di Desa Betelen Kecamatan Tombatu."

5 Kementerian Dalam Negeri, Peraturan Menteri Dalam Negeri Tentang Pengelolaan Keuangan desa, Permendagri Nomor 20 Tahun 2018, Berita Negara Republik Indonesia Nomor 611 Tahun 2018, Ps. 1 angka 6. bertanggungjawab mengenai dana desa tersebut harus memahami pengelolaan keuangan desa.

Sistem keuangan desa didistribusikan secara cuma-cuma (gratis) melalui pemerintah kabupaten/kota kepada desa di seluruh Indonesia. Pelatihan Siskeudes bagi perangkat desa maupun pembina di tingkat kabupaten/kota biayanya dianggarkan dalam APBD masing-masing. Selain gratis, Siskeudes juga memiliki banyak keunggulan. Oleh karena itu, berbagai kalangan, mulai dari Komisi XI DPR RI, Presiden Joko Widodo, hingga Ketua KPK menghimbau agar Siskeudes dapat diimplemetasikan oleh desa-desa di seluruh Indonesia. Saat ini, 69.875 dari total 74.957 desa telah mengimplementasikan Siskeudes.

Menurut survey BPKP, pengetahuan SDM perangkat desa sangat minim dalam hal keuangan desa, padahal uang yang harus dikelola di desa sangat banyak. ${ }^{6}$ Perangkat desa minimal terdiri atas Kepala desa Sekeretaris desa, Kepala urusan keuangan, dan Kepala-kepala urusan, dan Kepalakepala seksi, seperti Kaur Pemerintahan, Kaur Kesra, dll.

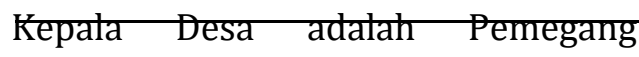

Kekuasaan Pengelolaan Keuangan Desa

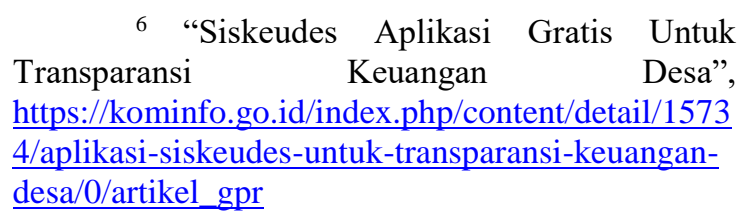


dalam kepemilikan kekayaan milik Desa yang dipisahkan.

Dalam melaksanakan Kekuasaan Pengelolaan Keuangan Desa sebagaimana dimaksud, Kepala Desa menguasakan sebagian kekuasaannya kepada Perangkat Desa selaku Pelaksana Pengelolaan Keuangan Desa.

Perangkat Desa selaku Pelaksana Pengelolaan Keuangan Desa sebagaimana dimaksud terdiri atas:

a. Sekretaris Desa;

b. Kaur dan Kasi; dan

c. Kaur keuangan.

Dapat dikatakan, yang menjadi Pengelolaan Keuangan Desa adalah:

1) Kepala Desa, baik sebagai Pemegang Kekuasaan Pengelolaan Keuangan Desa, dapat juga bertindak sebagai Pengelolaan Keuangan Desa secara langsung;

2) Sekretaris Desa;

3) Kaur dan Kasi;

4) Kaur keuangan.

Itulah gambaran umum tentang aparat desa yang menjadi Pemegang Kekuasaan Pengelolaan Keuangan Desa dan Pengelola Keuangan Desa. Dapat dikatakan Kepala Desa adalah Pemegang Kekuasaan Pengelolaan Keuangan Desa berdasarkan kewenangan distribusi, sedangkan Sekretaris Desa, Kaur dan Kasi, serta Kaur keuangan adalah Pemegang Kekuasaan Pengelolaan Keuangan Desa berdasarkan kewenangan delegasi dan mandat.
Kecamatan Tombatu yang berada di Kabupaten Minahasa Tenggara Provinsi Sulawesi Utara terdiri atas 11 (sebelas desa) yaitu: (1) Desa Betelen Kepala Desa Jeffry O.S. Tumiwa; (2) Desa Betelen Satu Kepala Desa Dedie Manopo; (3) Kali Desa Kepala Desa Aneke R. Mokat S.Pd; (4) Desa Kali Oki Kepala Desa Vanly Pangoulu; (5) Desa Tombatu Kepala Desa Desie I. Watania; (6) Desa Tombatu Satu Kepala Desa Sartje Lalogiroth; (7) Desa Tombatu Tiga Selatan Kepala Desa Ruben J. Ponaag, S.Pd; (8) Desa Tombatu Tiga Timur Kepala Desa Aries J. Runturambi; (9) Desa Tonsawang Kepala Desa Marthius Dokal; (10) Desa Tonsawang Satu Kepala Desa Rens A. Kamuh; (11) Desa Pisa Kepala Desa Alex D. B. Roong.

Kecamatan Tombatu yang terdiri atas sebelas desa dengan sebelas Kepala desa, maka di Kecamatan Tombatu terdapat juga sebelas Sekretaris Desa dan sebelas Kepala urusan keuangan, dan beberapa Kepala urusan dan Kepala seksi lainnya.

Kondisi mitra dapat dikemukakan:

- Pengelolaan keuangan desa di Kecamatan Tombatu kebanyakan belum berdasarkan Asas Pengelolaan Keuangan Desa yang dinyatakan di dalam Permendagri Nomor 20 Tahun 2018 yaitu: transparan, akuntabel, partisipatif serta dilakukan dengan tertib dan disiplin anggaran; dan pengelolaan keuangan Desa dalam masa 1 (satu) tahun anggaran mulai 
tanggal 1 Januari sampai dengan tanggal 31 Desember.

- Pemanfaatan keuangan desa kurang partisipatif artinya penetapan sasaran pembangunan fisik sebagai perwujudan penggunaan keuangan desa, kurang memperhatikan aspirasi masyarakat sebagai pengguna akhir dari hasil pembangunan tersebut.

- Pemanfaatan keuangan desa kurang menyentuh peningkatan dan pembinaan kewurausahaan masyarakat yang dapat memberikan kontribusi pada peningkatan kesejahteraan masyarakat.

- Pemanfaatan keuangan desa kurang menyentuh peningkatan dan pembinaan pemberdayaan masyarakat desa Kecamatan Tombatu yang kebanyakan adalah petani dan peternak.

- Pemanfaatan keuangan desa belum menjadikan suatu desa mandiri dalam membangun dan mengembangkan desa agar menjadi desa yang mandiri dan kuat.

- Adanya pembangunan fisik yang merupakan perwujudan pemanfaatan keuangan desa yang tidak tuntas pelaksanaannya sehingga memberikan kesan kurang maksimalnya penggunaan keuangan desa.

- Pengelolaan keuangan desa di Kecamatan Tombatu belum menerapkan sistem kontrol berasakan partitipasi, artinya masyarakat dikutsertaan sebagai salah satu komponen sistem dalam pengawasan sebagai upaya pencegahan terjadinya penyalahgunaan keuangan.

- Kebanyakan desa di Kecamatan Tombatu masih memiliki banyak kelemahan dalam menggunakan aplikasi sistem keuangan desa. Memang ada beberapa desa yang sudah terbilang mampu menggunakan aplikasi tersebut.

- Pengoperasian aplikasi sistem keuangan desa sebagian besar dilakukan oleh para Sekretaris Desa sehingga sering aplikasi sistem keuangan desa menjadi terbengkalai karena Sekretaris Desa juga mempunyai beberapa fungsi yang lain.

- Telah dilakukan pelatihan terkait aplikasi sistem keuangan desa, akan tetapi belum ada pelatihan yang maksimal terkait dasar-dasar pengelolaan keuangan desa berdasarkan Permendagri Nomor 20 Tahun 2018.

- Masih kurangnya pemahaman masyarakat khususnya para perangkat desa terkait konsep dasar pengelolaan keuangan desa berdasarkan Permendagri Nomor 20 Tahun 2018.

- Kurangnya informasi atau akses terhadap sistem keuangan desa pada umumnya dan sistem keuangan desa 
berdasarkan Permendagri Nomor 20 Tahun 2018.

\section{TINJAUAN PUSTAKA}

Implementasi kebijakan pada dasarnya juga mengukur akan keberhasilan atau kegagalan suatu hasil kebijakan yang secara nyata dilaksanakan dilapangan oleh para implementator dan bagaimana dampaknya terhadap masyarakat maupun stakeholder-nya, sebagaimana dikemukakan oleh Saefullah (2007:39) "pada tingkat pelaksanaan kebijakan menyangkut bagaimana atau sejauhmana suatu kebijakan bisa dilaksanakan dalam dunia nyata.". Pemahaman tentang pelaksanaan kebijakan bukan hanya dimiliki oleh aparat lembaga dan aparat pelaksana, tetapi juga oleh masyarakat atau pihak-pihak yang menjadi sasaran kebijakan".

Grindle melalui pemikirannya yang terkenal yaitu Implementation as A Political and Administrative Proces dimana ide dasarnya adalah bahwa setelah kebijakan ditransformasikan, barulah implementasi kebijakan dilakukan dan keberhasilannya ditentukan oleh derajat implementability dari kebijakan tersebut. Grindle (1980:5) lebih lanjut mengemukakan bahwa pengukuran keberhasilan implementasi kebijakan dapat ditentukan oleh dua hal, yaitu oleh isi kebijakan (content of policy) dan konteks (context of policy) implementasinya.
Isi kebijakan, mencakup hal-hal sebagai berikut:

1. Kepentingan yang terpengaruh oleh kebijakan (Interst Affected)

2. Jenis manfaat yang akan dihasilkan (Type of Benefits)

3. Derajat perubahan yang diinginkan (Extent of change Envision)

4. Kedudukan pembuat kebijakan (Site of Decision Making)

5. Pelaksana program (Program Implementer)

6. Sumber daya yang dikerahkan (Resources Commited)

Sementara itu, konteks implementasinya adalah:

1. Kekuasaan, kepentingan dan strategi aktor yang terlibat (Power, Interest and Strategy of Actor Involved)

2. Karakteristik lembaga dan penguasa (Institutional and Regime Characteristic)

3. Kepatuhan dan daya tanggap (Compliance and esponsiveness)

Model Implementasi Kebijakan tersebut disebut Model Grindle. Model implementasi ini lebih menonjolkan sisi politik dan pemerintahannya yakni actoraktor yang terlibat dalam pembuatan kebijakan serta dampak dikelurakannya suatu kebijakan yakni keberhasilan dan kegagalan suatu kebijakan itu bergantung dari isi kebijakan itu sendiri (content) dan kondisi dari kebijakan itu sendiri (konteks). 


\section{PEMBAHASAN}

\section{Pengelolaan Keuangan Desa}

Anggaran Pendapatan dan Belanja Desa merupakan dasar pengelolaan keuangan Desa dalam masa 1 (satu) tahun anggaran mulai tanggal 1 Januari sampai dengan tanggal 31 Desember.

Menurut James A.F Stoner, pengelolaan merupakan proses perencanaan, pengorganisasian, pengarahan dan pengawasan usaha-usaha para anggota organisasi dan pengguna sumberdayasumberdaya organisasi lainnya agar mencapai tujuan organisasi yang telah ditetap-kan. Menurut Arif (2007:32) pengelolaan keuangan desa adalah keselu-ruhan kegiatan yang meliputi peren-canaan, penganggaran, penatausaha-an, pelaporan, pertanggung-jawaban, dan pengawasan keuangan desa.

Berdasarkan Peraturan Menteri alam Negeri Nomor 4 Tahun 2007 Pasal 1 yang dimaksud dengan pengelolaan adalah rangkaian kegiatan mulai dari perencanaan, pengadaan, penggunaan, penatausahaan, penilaian, pembinaan, pengawasan dan pengendalian. Pengelolaan atau disebut juga dengan manajemen dalam pengertian umum adalah suatu seni, ketrampilan, atau keahlian, yakni seni dalam menyelesaikan pekerjaan melalui orang lain atau keahlian untuk menggerakkan orang melakukan seuatu pekerjaan.

Sedangkan menurut Permen-dagri Nomor 20 Tahun 2018 Pengelolaan
Keuangan Desa adalah keseluruhan kegiatan yang meliputi perencanaan, pelaksanaan, penatausahaan, pelaporan, dan pertanggungjawaban keuangan Desa.

Peraturan Menteri Dalam Negeri Nomor 37 tahun 2007 tentang Pedoman Pengelolaan Keuangan Desa, Pemerintah daerah mempunyai kewenangan yang ebih luas dalam pengelolaan daerahnya. Salah satu bentuk kepedulian pemerintah terhadap pengembangan wilayah pedesaaan adalah adanya anggaran pembangunan secara khusus yang dicantumkan dalam Anggaran Pendapatan dan Belanja Daerah (APBD) untuk pembangunan wilayah pedesaan, yakni dalam bentuk Alokasi Dana Desa (ADD). Inilah yang kemudian melahirkan suatu proses baru tentang desentralisasi desa diawali dengan digulirkannya Alokasi Dana Desa (ADD) (Nyoman 2005:24).

\section{Siklus Pengelolaan Keuangan Desa}

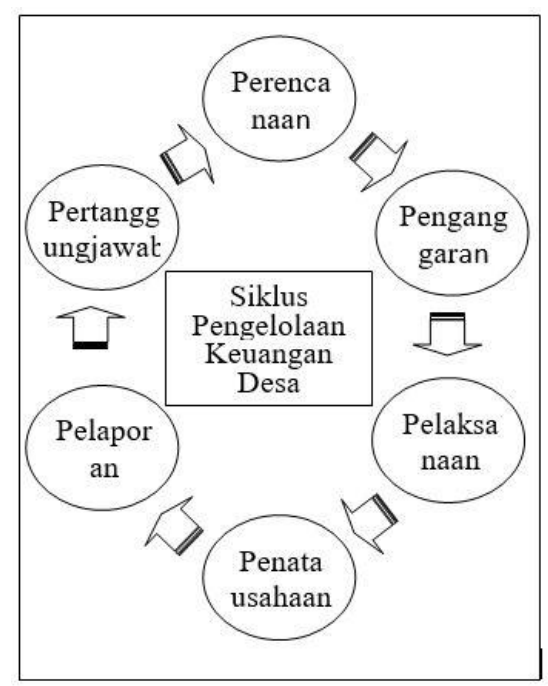


Permendagri No. 20 Tahun 2018 tentang pengelolaan keuangan desa yaitu sebagai berikut menjelaskan

Pengelolaan keuangan Desa sebagaimana dimaksud dilakukan dengan Basis Kas. Basis Kas sebagaimana dimaksud merupakan pencatatan transaksi pada saat kas diterima atau dikeluarkan dari rekening kas Desa. Pengelolaan keuangan Desa dapat dilakukan dengan menggunakan sistem informasi yang dikelola Kementerian dalam Negeri.

Perencanaan pengelolaan keuangan Desa merupakan perencanaan penerimaan dan pengeluaran pemerintahan Desa pada tahun anggaran berkenaan yang dianggarkan dalam APB Desa. Sekretaris Desa mengoordinasikan penyusunan rancangan APB Desa berdasarkan RKP Desa tahun berkenaan dan pedoman penyusunan APB Desa yang diatur dengan Peraturan Bupati/Wali Kota setiap tahun. Materi muatan Peraturan Bupati/Wali Kota sebagaimana dimaksud paling sedikit memuat:

a. sinkronisasi kebijakan pemerintah daerah kabupaten/ kota dengan kewenangan Desa dan RKP Desa;

b. prinsip penyusunan APB Desa;

c. kebijakan penyusunan APB Desa;

d. teknis penyusunan APB Desa; dan

e. hal khusus lainnya.

Rancangan APB Desa yang telah disusun merupakan bahan penyusunan rancangan Peraturan Desa tentang APB Desa.
Sekretaris Desa menyampaikan Rancangan Peraturan Desa tentang APB Desa kepada Kepala Desa. Rancangan Peraturan Desa tentang APB Desa sebagaimana dimaksud disampaikan Kepala Desa kepada BPD untuk dibahas dan disepakati bersama dalam musyawarah BPD. Rancangan Peraturan Desa tentang APB Desa sebagaimana dimaksud disepakati bersama paling lambat bulan Oktober tahun berjalan. Dalam hal BPD tidak menyepakati rancangan Peraturan Desa tentang APB Desa yang disampaikan Kepala Desa, Pemerintah Desa hanya dapat melakukan kegiatan yang berkenaan dengan pengeluaran operasional penyelenggaraan pemerintahan Desa dengan menggunakan pagu tahun sebelumnya. Kepala Desa menetapkan Peraturan Kepala Desa sebagai dasar pelaksanaan kegiatan sebagaimana dimaksud.

Atas dasar kesepakatan bersama Kepala Desa dan BPD sebagaimana dimaksud, Kepala Desa menyiapkan Rancangan Peraturan Kepala Desa mengenai penjabaran APB Desa. Sekretaris Desa mengoordinasikan penyusunan Rancangan Peraturan Kepala Desa sebagaimana dimaksud.

Pelaksanaan pengelolaan keuangan Desa merupakan penerimaan dan pengeluaran Desa yang dilaksanakan melalui rekening kas Desa pada bank yang ditunjuk Bupati/ Wali Kota. Rekening kas 
Desa sebagaimana dimaksud dibuat oleh Pemerintah Desa dengan spesimen tanda tangan kepala Desa dan Kaur Keuangan. Desa yang belum memiliki pelayanan perbankan di wilayahnya, rekening kas Desa dibuka di wilayah terdekat yang dibuat oleh Pemerintah Desa dengan spesimen tanda tangan kepala Desa dan Kaur Keuangan. Nomor rekening kas Desa sebagaimana dimaksud dilaporkan kepala Desa kepada Bupati/Wali Kota. Bupati/Wali Kota melaporkan daftar nomor rekening kas Desa kepada Gubernur dengan tembusan Menteri melalui Direktur Jenderal Bina Pemerintahan Desa. Laporan sebagaimana dimaksud digunakan untuk pengendalian penyaluran dana transfer. Kaur Keuangan dapat menyimpan uang tunai pada jumlah tertentu untuk memenuhi kebutuhan operasional pemerintah Desa. Pengaturan jumlah uang tunai sebagaimana dimaksud ditetapkan dalam Peraturan Bupati/Wali Kota mengenai pengelolaan Keuangan Desa. Kepala Desa menugaskan Kaur dan Kasi pelaksana kegiatan anggaran sesuai tugasnya menyusun DPA paling lama 3 (tiga) hari kerja setelah Peraturan Desa tentang APB Desa dan Peraturan Kepala Desa tentang Penjabaran APB Desa ditetapkan. DPA sebagaimana dimaksud terdiri atas:
a. Rencana Kegiatan dan Anggaran Desa;
b. Rencana Kerja Kegiatan Desa; dan
c. Rencana Anggaran Biaya.

Rencana Kegiatan dan Anggaran Desa sebagaimana dimaksud merinci setiap kegiatan, anggaran yang disediakan, dan rencana penarikan dana untuk kegiatan yang telah dianggarkan. Rencana Kerja Kegiatan Desa sebagaimana dimaksud merinci lokasi, volume, biaya, sasaran, waktu pelaksanaan kegiatan, pelaksana kegiatan anggaran, dan tim yang melaksanakan kegiatan. Rencana Anggaran Biaya sebagaimana dimaksud satuan harga untuk setiap

kegiatan. Kaur dan Kasi pelaksana kegiatan anggaran menyerahkan rancangan DPA kepada Kepala Desa

melalui Sekretaris Desa paling lama 6 (enam) hari kerja setelah penugasan sebagaimana dimaksud.

Sekretaris Desa melakukan verifikasi rancangan DPA paling lama 15 (lima belas) hari kerja sejak Kaur dan Kasi menyerahkan rancangan DPA. Kepala Desa menyetujui rancangan DPA yang telah diverifikasi oleh Sekretaris Desa.

Penatausahaan keuangan dilakukan oleh Kaur Keuangan sebagai pelaksana fungsi kebendaharaan.

Penatausahaan sebagaimana dimaksud dilakukan dengan mencatat setiap penerimaan dan pengeluaran dalam buku kas umum. Pencataan pada buku kas umum sebagaimana dimaksud ditutup setiap akhir bulan. Kaur Keuangan wajib membuat buku pembantu kas umum yang terdiri atas:

a. buku pembantu bank; 
b. buku pembantu pajak; dan

c. buku pembantu panjar.

Buku pembantu bank sebagaimana dimaksud merupakan catatan penerimaan dan pengeluaran melalui rekening kas Desa. Buku pembantu pajak sebagaimana dimaksud merupakan catatan penerimaan potongan pajak dan pengeluaran setoran pajak. Buku pembantu panjar sebagaimana dimaksud merupakan catatan pemberian dan pertanggungjawaban uang panjar. Penerimaan Desa disetor ke rekening kas Desa dengan cara:

a. disetor langsung ke bank oleh Pemerintah, Pemerintah Provinsi dan Pemerintah Daerah Kabupaten/Kota;

b. disetor melalui bank lain, badan, lembaga keuangan dan/atau kantor pos oleh pihak ketiga; dan

c. disetor oleh Kaur Keuangan untuk penerimaan yang diperoleh dari pihak ketiga.

Pengeluaran atas beban APB Desa ilakukan berdasarkan RAK Desa yang telah disetujui oleh Kepala Desa. Pengeluaran atas beban APB Desa untuk kegiatan yang dilakukan secara swakelola dikeluarkan oleh Kaur Keuangan kepada Kaur dan Kasi pelaksana kegiatan anggaran atas dasar DPA dan SPP yang diajukan serta telah disetujui oleh Kepala Desa. Pengeluaran atas beban APB Desa untuk kegiatan yang dilakukan melalui penyedia barang/jasa dikeluarkan oleh Kaur Keuangan langsung kepada penyedia atas dasar DPA dan SPP yang diajukan oleh
Kasi pelaksana kegiatan anggaran dan telah disetujui oleh Kepala Desa. Pengeluaran atas beban APB Desa untuk belanja pegawai, dilakukan secara langsung oleh Kaur Keuangan dan diketahui oleh Kepala Desa. Pengeluaran atas beban APB Desa sebagaimana dimaksud dibuktikan dengan kuitansi pengeluaran dan kuitansi penerimaan. Kuitansi pengeluaran sebagaimana dimaksud ditandatangani oleh Kaur Keuangan. Kuitansi penerimaan sebagaimana dimaksud ditandatangani oleh penerima dana.

Kepala Desa menyampaikan laporan pelaksanaan APB Desa semester pertama kepada Bupati/Wali Kota melalui camat. Laporan sebagaimana dimaksud terdiri dari:

a. laporan pelaksanaan APB Desa; dan

b. laporan realisasi kegiatan.

Kepala Desa menyusun laporan sebagaimana dimaksud dengan cara menggabungkan seluruh laporan sebagaimana dimaksud 56 paling lambat minggu kedua bulan Juli tahun berjalan. Bupati/Wali Kota menyampaikan laporan konsolidasi

pelaksanaan APB Desa kepada Menteri melalui Direktur Jenderal Bina Pemerintahan Desa paling lambat minggu kedua Bulan Agustus tahun berjalan.

Pertanggungjawaban. Kepala Desa menyampaikan laporan pertanggungjawaban realisasi APB Desa kepada Bupati/Wali Kota melalui camat 
setiap akhir tahun anggaran. Laporan pertanggungjawaban sebagaimana dimaksud disampaikan paling lambat 3 (tiga) bulan setelah akhir tahun anggaran berkenaan yang ditetapkan dengan Peraturan Desa.

Laporan Pertanggungjawaban sebagaimana dimaksud merupakan bagian dari laporan penyelenggaraan Pemerintahan Desa akhir tahun anggaran. Bupati/Wali Kota menyampaikan laporan konsolidasi

realisasi pelaksanaan APB Desa kepada Menteri melalui Direktur Jenderal Bina Pemerintahan Desa paling lambat minggu kedua Bulan April tahun berjalan. Laporan sebagaimana dimaksud diinformasikan kepada masyarakat melalui media informasi. Informasi sebagaimana dimaksud paling sedikit memuat:

a. laporan realisasi APB Desa;

b. laporan realisasi kegiatan;

c. kegiatan yang belum selesai dan/atau tidak terlaksana;

d. sisa anggaran; dan

e. alamat pengaduan.

Kegiatan Pengelolaan Keuangan Desa dapat dilaksanakan dengan baik tentunya harus didukung diantaranya oleh sumber daya manusia yang kompeten dan berkualitas serta sistem dan prosedur keuangan yang memadai. Oleh karenanya, pemerintah desa harus memiliki struktur organisasi pengelolaan keuangan, uraian tugas, bagan alir, dan kriteria yang menjadi acuan dalam kegiatan pengelolaan keuangan desa.

\section{Asas-Asas Pengelolaan Keuangan Desa}

Keuangan Desa dikelola berdasarkan asas transparan, akuntabel, partisipatif serta dilakukan dengan tertib dan disiplin anggaran.

Yang dimaksud dengan asas transparan yaitu keterbukaan adalah asas yang melayani masyarakat untuk mendapatkan akses dan memperoleh informasi yang benar, jujur, dan tidak diskriminatif dalam penyelenggaraan pemerintahan pada umumnya dan penelolaan keuangan desa pada khususnya dengan tetap memperhatikan perlindungan atas hak asasi pribadi, golongan, dan rahasia lembaga

Akuntabilitas, adalah asas yang menentukan bahwa setiap kegiatan dan hasil akhir darl kegiatan penyelenggara pemerintahan pemerintahan pada umumnya dan penelolaan keuangan desa pada khususnya harus dapat dipertanggungjawabkan kepada masyarakat atau rakyat sebagai pemegang kedaulatan tertinggi dalam desa sesuai dengan ketentuan peraturan perundang-undangan yang berlaku.

\section{KESIMPULAN DAN SARAN}

\section{Kesimpulan}

1. Kebijakan mengenai pemberian Dana yang besar kepada Desa berdampak positif bagi perkembangan desa khususnya selama pembangunan fisik desa, namun dalam pengelolaan keuangan desa, belum diikuti dengan 
kualitas aparat pelaksana, kebijakan baru dan aturan pendukung yang baru, menyebabkan aparat pelaksana tidak mampu mengimbanginya.

2. Proses perumusan kebijakan dan pengelolaan keuangan merupakan suatu proses politik dan melibatkan berbagai aktor mulai Kepala Desa, BPD, kelompok masyarakat dan masyarakat masing-masing aktor memiliki kepentingan-kepentingan tertentu baik tersembunyi maupun terangterangan satu dengan yang lain saling berbenturan, sumber munculnya konfik kepentingan karena adanya kepentingan untuk memperoleh material lebih besar terjadi politisasi anggaran dimana ada mata anggaran yang tidak melalui proses perencanaan partisipasi masyarakat. Masing-masing desa kecamatan mitra.

3. Dalam pengelolaan keuangan desa, disediakan ruang publik untuk berpartisipasi dalam menyusun program dan kegiatan penyaringan aspirasi masyarakat melalui musrenbangdes, namun usulan masyarakat tersebut kalah bertarung dengan agenda institusi (Pemkab, Pemdes dan BPD serta elite lokal) yang mempunyai kepentingan tersendiri, seharusnya usulan masyarakat dirumuskan sebagai pijakan dalam menetapkan kebijakan umum anggaran.

4. Lemahnya kontrol masyarakat serta kurangnya sosialisasi mengenai pengelolaan keuangan desa kepada masyarakat serta dominasi dari beberapa stakeholder, maka kebijakan anggaran dipolitisasi oleh aktor-aktor yang terlibat dalam proses penyusunan dan penetapan APBD, sehingga masyarakat dirugikan.

\section{Saran}

1. Pendidikan dan pelatihan kepada pelaksana teknis pengelolaan keuangan desa dilakukan bukan hanya sekali, melainkan dilakukan secara berkala, Badan Pemberdayaan Masyarakat Desa Kabupaten melaksanakan pelatihan pengelolaan keuangan desa dan terus melaksanakan pendampingan. Berkaitan dengan hal tersebut, Pemerintah Kabupaten dan Pemerintah Kecamatan harus memaksimalkan pendamping desa sesuai dengan Peraturan Menteri Desa Nomor 3 Tahun 2015 tentang Pendampingan Desa, agar meningkatkan kapasitas, efektivitas dan akuntabilitas pemerintahan desa dan pembangunan Desa.

2. Dalam pembahasan anggaran APBDesa pada tahun selanjutnya, sebaiknya dilakukan ujicost effectiveness, uji relevansi, dan uji cost urgent yang dilakukan oleh PTPKD agar tidak mengarah kepada politisasi anggaran yang ujung-ujungnya mencari keuntungan pribadi, kelompok dan elite tertentu. Pemerintah desa sebaiknya melakukan kajian terlebih dahulu mengenai kebutuhankebutuhan dasar masyarakat desa sehingga pengambilan keputusan bukan berdasarkan hanya kepentingan sebagian masyarakat saja namun dapat mencakup semua kalangan. Hal ini dapat dilaksanakan dengan cara mengadakan survey tentang kepuasan masyarakat tentang pengelolaan keuangan desa pada tahun sebelumnya bekerjasama dengan dunia pendidikan atau dapat memanfaatkan mahasiswa KKN (apabila ada).

3. Pemerintah desa seharusnya mengambil sikap dan mempunyai prinsip dalam setiap pengambilan 
keputusan program yang ada. Sehingga meminimalisir dominasi pihak-pihak luar termasuk pemerintah kecamatan dan kabupaten. Yang terpenting adalah pelaksanaan pengelolaan keuangan desa berjalan sesuai dengan ketentuan yang berlaku.

4. Perlu adanya sosialisasi kepada masyarakat tentang keuangan desa serta sumber-sumber keuangan desa yang terbaru beserta fungsi-fungsi dari setiap anggaran sehingga, dapat meningkatkan partisipasi masyarakat dalam pengelolaan keuangan desa baik pada tahap perencanaan sampai pada tahap pengawasan. Hal ini sangat penting mengingat jumlah dana yang besar dapat membuat pelaksananya terjerat pada kesalahan-kesalahan. Sosialisasi tersebut dapat melalui beberapa kesempatan maupun dapat disampaikan dalam rapat dan dapat dibuatkan poster tentang mekanisme pengelolaan keuangan desa di Kantor Desa. Selain meningkatkan partisipasi masyarakat tercipta pula transparansi dalam pengelolaan keuangan desa.

\section{KEPUSTAKAAN}

“Analisis Sistem Pengelolaan Dana Desa Berdasarkan Regulasi Keuangan Desa". https://www.researchgate.net/public ation/323384179

"Badan Pusat Statistik Kabupaten Minahasa Selatan Nama-nama Kepala Desa Kabupaten MITRA." https://mitrakab.bps.go.id/statictable 2018/01/26/60/ daftar-namanama-kepala-desa-di-kabupatenminahasa-tenggara-2016.html
"Bupati Sumendap Minta Kepala SKPD dan Kumtua Harus Paham Pengelolaan Keuangan."

http://sulutdaily.com/bupatisumendap-minta-kepala-skpd-dankumtua-harus-paham-pengelolaankeuangan/

"Gelar Bimtek SISKEUDES, Pemkab Mitra Perkuat SDM Aparat Desa." https://beritamanado.com/gelarbimtek-siskeudes-pemkab-mitraperkuat-sdm-aparat-desa/

“Pengelolaan Keuangan Desa Permendagri 202018 - Keuangan Desa.info Mengawal Tata Kelola Keuangan Desa."

https://www.keuangandesa.info/ 2018/05/pengelolaan-keuangandesa-permendagri-20-2018.html

"Peningkatan Kemampuan Tata Kelola Keuangan Desa." http://pengabdian. lppm.itb.ac.id/pengabdian/laporanpe ngabdian/peningkatan-kemampuantata-kelola-keuangan-desa

"Siskeudes Aplikasi Gratis Untuk Transparansi Keuangan Desa." https://kominfo.go.id/index.php/cont ent/detail/15734/aplikasi-siskeudesuntuk-transparansi-keuangandesa/0/artikel gpr

https://beritamanado.com/gelar-bimteksiskeudes-pemkab-mitra-perkuatsdm-aparat-desa/ 
Indonesia. Peraturan Pemerintah Tentang Peraturan Pelaksanaan UndangUndang Nomor 6 Tahun 2014 tentang Desa. PP Nomor 43 Tahun 2014.

Indonesia. Peraturan-Pemerintah Tentang Perubahan Atas Peraturan Pemerintah Nomor 43 Tahun 2014 Tentang Peraturan Pelaksanaan UndangUndang Nomor 6 tahun 2014 Tentang Desa, PP Nomor 47 Tahun 2015.

Indonesia. Undang-Undang Tentang Desa, Nomor 6 Tahun 2014, LN Nomor 7 Tahun 2014, TLN Nomor 5495.

Kementerian Dalam Negeri, Peraturan Menteri Dalam Negeri Tentang Pengelolaan Keuangan desa, Permendagri Nomor 20 Tahun 2018, Berita Negara Republik Indonesia Nomor 611 Tahun 2018.

Kementerian Dalam Negeri, Lampiran Peraturan Menteri Dalam Negeri Tentang Pengelolaan Keuangan desa,
Permendagri Nomor 20 Tahun 2018.

Kementerian Komunikasi dan Informatika, "Aplikasi Siskeudes untuk Transparansi Keuangan Desa", https://kominfo.go.id/index.php/cont ent/ detail/15734/aplikasisiskeudes-untuk-transparansikeuangan-desa/0/artikel gpr

Khoiriah, Siti.; Utia Meylina, "Analisis Sistem Pengelolaan Dana Desa", MasalahMasalah Hukum, Jilid 46, No. 1, Januari 2017.

Tumiwa, Vijay L. "Kinerja Dinas Pertanian Kabupaten Minahasa Tenggara Dalam Program Bantuan Peningkatan Hasil Pertanian Di Desa Betelen Kecamatan Tombatu." 